\title{
Fuzzy Simple Additive Weighting Algorithm to Determine Land Suitability for Crop in Minahasa Tenggara
}

\author{
Eko Sediyono \\ Graduate School of Information \\ System, SWCU \\ JI. Diponegoro 52-60 Salatiga, \\ Indonesia
}

\author{
Adi Setiawan \\ Faculty of Science and \\ Mathematics, SWCU \\ Jl. Diponegoro 52-60 Salatiga, \\ Indonesia
}

\author{
Daniel Riano Kaparang \\ Student of Graduate School of \\ Information System, SWCU \\ Jl. Diponegoro 52-60 Salatiga, \\ Indonesia
}

\begin{abstract}
The change of geographical situation such as weather and climate make farmers difficult to prepare the land for suitable crop. Consequently they depend on rainwater rice field. This paper explain the use of fuzzy simple additive weighting to rank the alternate crops suitable for planted in each sub district in Minahasa Tenggara. This information system can be used by local government and farmers to determine the type of crop to be planted. This information based on geophysics data existing in Dept. of Agriculture and Central Bureau of Statistics.
\end{abstract}

\section{General Terms}

Fuzzy Classification, Land-use Classification

\section{Keywords}

Fuzzy Simple Additive Weighting, Land suitability, crop.

\section{INTRODUCTION}

Planning management of land use is one of the factors to achieve the land use optimization. It is because of the limitation of the number of land and non renewable land resources, the occurrence of the damage due to the lack of land utilization, the reduction of water catchment area resulting from the alteration use of forest land into agricultural land area [1]. In support of food self-sufficiency government of Minahasa Tenggara district through Dept. of agriculture and farm will do land treatment of about 80 ha unmanaged land in Pusomaen. This area and the surrounding area is the areas those are suffered from land and food crisis caused by the sleep land.

From the pre analysis of Central Statistic Bureau (BPS) data the increasing production of rice in North Sulawesi is not balance with the increasing of need. On 2009, rice production in North Sulawesi is about 16.103 tons and the need is 11.463 tons [2]. On 2010 rice production reach 33.820 tons, but the need increase sharply to 96.766 tons over the production in North Sulawesi. As a main source of rice production, Minahasa Tenggara trying to increase food production by optimizing food land. It is not just rice but also corn and cassava.

The strategy of land use optimization as the agricultural cultivation need to be supported by the provision of all facilities and infrastructure required by improving its human resources and strengthening the capacity of institution. The first step in maintaining the stability of the food security and increase farmers' economy is utilizing the land for food plots, besides naturally preserve the ecosystem and reduce opening agricultural land by clearing forests land.

Clearing land for crops need proper evaluation and analysis according to the conditions of the environment. On 2011 Food and Agriculture Organization (FAO) renew the existing land evaluation indicators. Those indicators are land conformity, comparative advantage with the input that is required, the land use technology, evaluation of the physical condition of land, the socio-economic conditions, conformity on the sustainable land use without damaging nature, and the characteristic of land use [3]. Furthermore, this FAO land evaluation technique is called an FAO model.

This paper discusses an algorithm suitable to evaluate the land use that is Fuzzy Simple Additive Weighting (SAW) algorithm. This algorithm requires a number of alternatives and criteria that support the suitability of land for food crops. To simplify the criteria of FAO model, we reduce the criteria to be five criteria, those are rainfall intensity, the texture of land, irrigation, and the climate. We study the use of fuzzy SAW algorithm in determining the appropriate type of food plants to grown in sub districts of Minahasa Tenggara.

\section{LITERATURE REVIEW}

\subsection{Fuzzy Simple Additive Weighting Algorithm}

Fuzzy simple additive weighting algorithm is one of fuzzy multi attribute decision making algorithm that is used to choose the best alternative among alternatives by using certain criteria [4]. There are two steps to approach, that are calculating the aggregation of all decisions that approach to all destinations on each alternative, and then ranking the alternative against each of the decision based on the aggregation results [5]. The algorithm is [6]:

- $\quad$ Put a value on each alternate $\left(A_{i}\right)$ on each criteria $\left(C_{j}\right)$ that is determined. The given value is a set of crisp number $i=\{1,2, \ldots, m\} ; j=\{1,2, \ldots, n\}$

- $\quad$ Give weight $(W)$ to the crisp number that is determined.

- Do normalization to plot the membership degree of each fuzzy element by calculating the normalized performance value $\left(r_{i j}\right)$ from alternate $A_{i}$ to attribute $C_{j}$ based on the equation that adjusted with the type of an attribute with maximum value (MAX $X_{i j}$ ) or minimum value (MIN $X_{i j}$ ).

- Rank all alternates by multiply the normalized matrix $(R)$ with the weighted value $(W)$.

- $\quad$ Determine the preference value for each alternate $(V i)$ by adding the product of normalized matrix $(R)$ with the weighted value $(W)$. The maximum $V_{i}$ define that the alternate is better.

\subsection{Alternate and Suitability Land}

Alternate is determined for sub district in the Minahasa Tenggara through the type of food crops to be planted by calculating an average of the suitability of any food crop in a 
fuzzy based on criteria of growing plants. The type of the specified food crops include paddy, dry field paddy ( $g \circ g o$ ), corn, and cassava. Each alternate is denoted as $P_{1}, P_{2}, P_{3}$, and $P_{4}$.

Criteria is denoted by land class of multiple factor. The classification is using some factors to classify the observed object [3]. The factors that determined must be prominent characteristics. It is allow other people to use them without having to understand the whole characteristics used in the system of land use.

The prominent characteristic is determined from the average rainfall per year, soil texture, the number of irrigation, climate, and topography [8]. The alternate and criteria of land use that has been determined can be seen in Table 1 .

Table 1. Sub district and the characteristic of land use

\begin{tabular}{|c|c|c|c|c|c|}
\hline Sub-dist & $\begin{array}{c}\text { Rainfall } \\
\text { (mm/y } \\
\text { ear) }\end{array}$ & Soil texture & $\begin{array}{c}\text { Irrigation } \\
\text { (times/ye } \\
\text { ar) }\end{array}$ & Climate & $\begin{array}{c}\text { Topo } \\
\text { graphy } \\
\text { (m-amsl) }\end{array}$ \\
\hline Ratahan & 2955 & $\begin{array}{l}\text { Sandy clay } \\
\text { soil, dusty } \\
\text { clay soil, } \\
\text { clay soil }\end{array}$ & 41 & 5.43 & 600 \\
\hline $\begin{array}{l}\text { Pusoma } \\
\text { en }\end{array}$ & 2984 & Sandy clay & 341 & 5.38 & 600 \\
\hline Belang & 3241 & Sandy clay & 55 & 4.95 & 200 \\
\hline $\begin{array}{l}\text { Ratatoto } \\
\mathrm{k}\end{array}$ & 2959 & $\begin{array}{l}\text { Clay, } \\
\text { Sandy clay }\end{array}$ & 22 & 5.42 & 500 \\
\hline $\begin{array}{l}\text { Tombat } \\
\mathrm{u}\end{array}$ & 2271 & $\begin{array}{l}\text { Clay, dusty } \\
\text { clay, dust }\end{array}$ & 81 & 7.07 & 600 \\
\hline $\begin{array}{l}\text { Touluaa } \\
n\end{array}$ & 3137 & $\begin{array}{l}\text { Clay, dusty } \\
\text { clay, dust }\end{array}$ & 432 & 5.12 & 500 \\
\hline $\begin{array}{l}\text { North } \\
\text { Tombat } \\
\text { u }\end{array}$ & 3005 & $\begin{array}{l}\text { Sandy soil, } \\
\text { dusty soil, } \\
\text { soil }\end{array}$ & 156 & 5.34 & 500 \\
\hline $\begin{array}{l}\text { East } \\
\text { Tombat } \\
\text { u }\end{array}$ & 3360 & $\begin{array}{l}\text { Sandy soil, } \\
\text { dusty soil, } \\
\text { soil }\end{array}$ & 337 & 4.77 & 500 \\
\hline $\begin{array}{l}\text { South } \\
\text { Tombat } \\
\text { u }\end{array}$ & 3097 & $\begin{array}{l}\text { Clay, dusty } \\
\text { clay, dust }\end{array}$ & 133 & 5.18 & 400 \\
\hline $\begin{array}{l}\text { Silian } \\
\text { Raya }\end{array}$ & 2770 & Sandy clay & 149 & 5.79 & 400 \\
\hline $\begin{array}{l}\text { East } \\
\text { Ratahan }\end{array}$ & 2812 & $\begin{array}{l}\text { Sandy clay } \\
\text { soil, dusty } \\
\text { clay soil, } \\
\text { clay soil }\end{array}$ & 76 & 5.71 & 600 \\
\hline Pasan & 2964 & Sandy clay & 854 & 5.41 & 300 \\
\hline
\end{tabular}

\section{RESULT AND DISCUSSION}

\subsection{Fuzzy values to classify Criteria}

Rainfall intensity is classified as very wet $>3,000 \mathrm{~mm} /$ year, wet 2,501-3,000 mm/year, moderate or humid 2,001-2,500 $\mathrm{mm} /$ year, dry 1,501-2,000 $\mathrm{mm} /$ year, very dry $<1,500$ $\mathrm{mm} /$ year.

Soil texture is classified as coarse (sand, sand clays) with weighted value $0-0.2$, a little rough (clay sand) with weighted value $0.21-0.4$, moderate (clay, clay dust, dust) with weighted value $0.41-0.6$, rather fine (sandy clay soil, dusty clay soil, clay soil) with weighted value $0.61-0.8$, fine (sandy soil, dusty soil, soil) with weighted value $0.81-1$.
Schmidt - Ferguson [8] classified climate based on the rainfall by calculating the average of dry season divide by the average of wet season multiply with $100 \%$. The Irrigation is classified by calculating the amount of irrigation per year.

Topography is classified in five class based on height of above mean seal level (amsl). This classes are height range from $0-200$ meter has weight $0-0.2$; height range from 201 - 400 meter amsl has weight $0.21-0.4$, height range from $401-600$ meter amsl has weight $0.41-0.6$, height range from $601-800$ meter amsl has weight $0.61-0.8$ dan height > 800 meter amsl has weight $0.81-1$.

The result of the fuzzy calculation using increasing linear representation (eq 1) and for all criteria the calculation can be seen in Table 2.

$$
\mu[x]=\left\{\begin{array}{rc}
0 ; & x \leq a \\
\frac{x-a}{b-a} ; & a \leq x \leq b \\
1 ; & x \geq b
\end{array}\right.
$$

Table 2. Fuzzy Result for all Criteria

\begin{tabular}{|l|r|r|r|r|r|}
\hline Sub-dist & $\begin{array}{c}\text { Rainfall } \\
\text { (mm/year } \\
\text { ) }\end{array}$ & $\begin{array}{c}\text { Soil } \\
\text { texture }\end{array}$ & $\begin{array}{c}\text { Irrigat } \\
\text { ion } \\
\text { (times } \\
\text { /year) }\end{array}$ & $\begin{array}{c}\text { Clim } \\
\text { ate }\end{array}$ & $\begin{array}{c}\text { Topo } \\
\text { graph } \\
\text { y } \\
(\mathrm{m}- \\
\text { amsl })\end{array}$ \\
\hline \hline Ratahan & 0.98 & 0.65 & 0.05 & 0.89 & 0.75 \\
\hline Pusomaen & 0.99 & 0.32 & 0.38 & 0.88 & 0.75 \\
\hline Belang & 1.00 & 0.30 & 0.06 & 0.81 & 0.25 \\
\hline Ratatotok & 0.98 & 0.28 & 0.02 & 0.89 & 0.63 \\
\hline Tombatu & 0.71 & 0.53 & 0.09 & 1 & 0.75 \\
\hline Touluaan & 1.00 & 0.58 & 0.48 & 0.84 & 0.50 \\
\hline $\begin{array}{l}\text { North } \\
\text { Tombatu }\end{array}$ & 1.00 & 0.90 & 0.17 & 0.88 & 0.38 \\
\hline East Tombatu & 1.00 & 0.95 & 0.37 & 0.77 & 0.25 \\
\hline $\begin{array}{l}\text { South } \\
\text { Tombatu }\end{array}$ & 1.00 & 0.92 & 0.15 & 0.85 & 0.63 \\
\hline Silian Raya & 0.91 & 0.55 & 0.17 & 0.96 & 0.38 \\
\hline East Ratahan & 0.92 & 0.45 & 0.08 & 0.94 & 0.38 \\
\hline Pasan & 0.99 & 0.28 & 0.95 & 0.89 & 0.38 \\
\hline
\end{tabular}

\subsection{Calculation using Fuzzy Simple Additive Weighting}

After the fuzzy value obtained from the overall criteria then determine the weighted vector value $(w)$ for each criteria as be seen in the bottom of Table 3. Next step is calculating the normalized rating performance $\left(r_{i j}\right)$ for each attribute and each criterion. Because the value assigned to each alternative for each criteria, then it is assumed that these criteria are criteria of profit. The results can be seen in Table 3 bellow.

Table 3. Normalized Criteria $\left(r_{i j}\right)$

\begin{tabular}{|l|r|r|r|r|r|}
\hline Sub district & $\begin{array}{c}\text { Rainfall } \\
\text { (mm/year) }\end{array}$ & $\begin{array}{c}\text { Soil } \\
\text { texture }\end{array}$ & $\begin{array}{c}\text { Irrigat } \\
\text { ion } \\
\text { (count } \\
\text { /year) }\end{array}$ & $\begin{array}{c}\text { Clim } \\
\text { ate } \\
\text { graphy } \\
(\mathrm{m}- \\
\text { amsl) }\end{array}$ & $\begin{array}{c}\text { Topo } \\
\text { Ratahan }\end{array}$ \\
\hline \hline Pusomaen & 0.982 & 0.68 & 0.05 & 0.89 & 1 \\
\hline Belang & 1 & 0.32 & 0.06 & 0.81 & 0.33 \\
\hline Ratatotok & 0.98 & 0.29 & 0.03 & 0.89 & 0.83 \\
\hline
\end{tabular}




\begin{tabular}{|l|r|r|r|r|r|}
\hline Tombatu & 0.71 & 0.56 & 0.09 & 1 & 1 \\
\hline Touluaan & 1 & 0.61 & 0.50 & 0.87 & 0.83 \\
\hline $\begin{array}{l}\text { North } \\
\text { Tombatu }\end{array}$ & 1 & 0.95 & 0.18 & 0.91 & 0.83 \\
\hline East Tombatu & 1 & 1 & 0.39 & 0.80 & 0.83 \\
\hline $\begin{array}{l}\text { South } \\
\text { Tombatu }\end{array}$ & 1 & 1 & 0.15 & 0.88 & 0.67 \\
\hline Silian Raya & 0.92 & 1 & 0.17 & 1 & 0.67 \\
\hline East Ratahan & 0.94 & 0.90 & 0.09 & 1 & 1 \\
\hline Pasan & 1 & 0.56 & 1 & 1 & 0.67 \\
\hline $\begin{array}{l}\text { Weighted } \\
\text { vector (w) }\end{array}$ & 0.68 & 0.50 & 0.28 & 0.88 & 0.56 \\
\hline
\end{tabular}

The last step of fuzzy SAW calculation is ranking preference value $\left(V_{i}\right)$ come from sum of weighted vector multiplication $(w)$ and normalized matrix $\left(r_{i j}\right)$. The result of the calculation can be seen in Table 4 .

Table 4. Ranking $\left(V_{i}\right)$

\begin{tabular}{|l|r|}
\hline \multicolumn{1}{|c|}{ Sub-dist } & \multicolumn{1}{c|}{ Rank } \\
\hline \hline Ratahan & 2.38 \\
\hline Pusomaen & 2.30 \\
\hline Belang & 1.76 \\
\hline Ratatotok & 2.08 \\
\hline Tombatu & 2.23 \\
\hline Touluaan & 2.36 \\
\hline $\begin{array}{l}\text { North } \\
\text { Tombatu }\end{array}$ & 2.48 \\
\hline East Tombatu & 2.47 \\
\hline $\begin{array}{l}\text { South } \\
\text { Tombatu }\end{array}$ & 2.38 \\
\hline Silian Raya & 2.43 \\
\hline East Ratahan & 2.56 \\
\hline Pasan & 2.50 \\
\hline
\end{tabular}

\subsection{Analysis of the Result}

From the ranking on Table 4, we cannot yet determine whether a particular sub district can be planted food crops such as rice paddy irrigation, dry field paddy (gogo), corn and cassava. In this analysis we calculate the amount of the requirement of growing plants with the approach of each criterion specified previously in the fuzzy. The result is presented in Table 5 .

Table 5. Requirement of growing plats by using Criteria approach

\begin{tabular}{|l|c|c|c|c|c|c|}
\hline $\begin{array}{c}\text { Alternat } \\
\mathrm{e}\end{array}$ & $\begin{array}{c}\text { Rainfal } \\
1\end{array}$ & $\begin{array}{c}\text { Soil } \\
\text { textur } \\
\mathrm{e}\end{array}$ & $\begin{array}{c}\text { Irrigat } \\
\text { ion }\end{array}$ & $\begin{array}{c}\text { Clim } \\
\text { ate }\end{array}$ & $\begin{array}{c}\text { Topo } \\
\text { graph } \\
\mathrm{y}\end{array}$ & $\begin{array}{c}\text { Amou } \\
\mathrm{nt}\end{array}$ \\
\hline \hline $\begin{array}{l}\text { Irrigatio } \\
\mathrm{n} \text { paddy } \\
\text { (P1) }\end{array}$ & 0.800 & 0.7 & 0.111 & 0.44 & 0.500 & 2.555 \\
\hline $\begin{array}{l}\text { dry field } \\
\text { paddy } \\
\text { (gogo }) \\
\text { (P2) }\end{array}$ & 0.600 & 0.6 & 0.055 & 0.44 & 0.500 & 2.200 \\
\hline $\begin{array}{l}\text { Corn } \\
\text { (P3) }\end{array}$ & 0.600 & 0.6 & 0.011 & 0.44 & 0.375 & 2.031 \\
\hline $\begin{array}{l}\text { Cassava } \\
\text { (P4) }\end{array}$ & 0.520 & 0.5 & 0.011 & 0.25 & 0.250 & 1.540 \\
\hline
\end{tabular}

From these results it can be determined that the food commodities can be planted in a particular sub district. Suppose in Ratahan value rank 2.38 is matching with gogo because the nearest ranking value with the amount of requirement of growing plants with the criteria approach is 2.2004. The reality on the field that sub district Ratahan has data of rainfall, irrigation, soil texture, climate and topography suitable for rice plant gogo. It can be seen also to other food such as alternative irrigation of rice planted in suitable districts of North Tombatu, East Tombatu, East Ratahan, Pasan, Silian Raya. Gogo rice is suitable planted in Ratahan, Pusomaen, Tombatu, Touluaan, and South Touluaan. Corn is suitable planted in Ratatotok. Cassava is suitable planted in Belang.

To clarify the result we plot it on the map from google map API, that can be seen in figure 1 . The rank is classified into three classes, that is very suitable, suitable, and unsuitable. The classes of the rank are marked with the different color. On that map there are also information about how much land area suitable for a specific plant. This information can be used by local government to control the productivity of crop on their area.

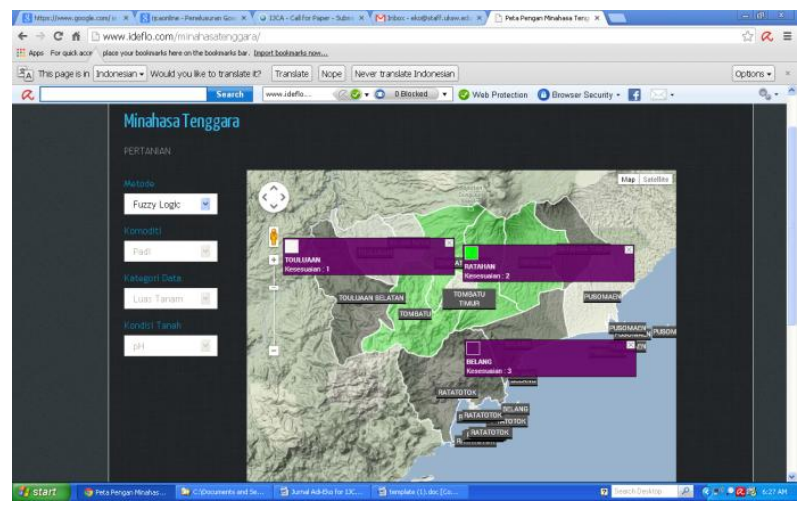

Fig 1: Rank Plot of Land Suitability in Minahasa Tenggara

\section{CONCLUDING REMARK}

\subsection{Conclusion}

From the results of the analysis it can be concluded that the fuzzy simple additive weighting algorithms (SAW) can be used to determine the type of food crops grown on a given area by using a number of criteria such as soil texture, rainfall, irrigation, climate and topography. Validation with the data in the field also show a match with data calculated by using fuzzy.

\subsection{Future Research}

Upcoming research is expected to use more criteria in accordance with the standardization of land suitability or standardization of FAO to strengthen data and results. Furthermore this research can be used as input to the Department of agriculture in Minahasa Tenggara District. It can also be used in other regions to increase food productivity.

The use of google map is somewhat imposed to show the spread of suitable area for certain crop. It is better if we use landsat image from Satellite as explain by Salman at.al [9] and Zhan et.al [10].

\section{ACKNOWLEDGMENTS}

We thank to Winsy Weku as a local expert for the information and field consultation, such that this research can be done. We 
also thank to Higher Education Directorate (DIKTI) for the 2013 research grant, such that we can do the research in Minahasa Tenggara District.

\section{REFERENCES}

[1] Hardjowigeno Sarwono, Widiatmaka. . 2007, The evaluation of Land Suitability and land use Planning. Gadjah Mada University Press.

[2] The Central Bureau Of Statistics Of North Sulawesi,2009, Production and Demand of rice in North Sulawesi in 2009. http://sulut.bps.go.id/beras.php? pilih=2009 (downloaded on March 3th, 2013)

[3] Sitorus R. P. Santun., 2005, The Evaluation of Land Resources. Tarsito. Bandung.

[4] Kusumadewi, S.; Harjoko; A. Wardoyo, R.,2006, Fuzzy Multi Attribute Decision Making (Fuzzy MADM). Yogyakarta: Graha Ilmu.

[5] Kaparang Daniel R., Yos R. Beeh., Eko Sediyono, 2011, The Implementation of Fuzzy Multi-Attribute Decision Making By Simple Additive Weighting Approach to Help the Minahasa Church Pastor Mutation. Proceeding SNTI UNTAR Volume 8. No. 1, 2011.
[6] Wibowo Henry, 2010, MADM Tool: The Application of Sensitivity test for MADM Model using SAW and TOPSIS Method. SNATI. ISSN:1907-5022.

[7] Suhardiman, 2004, The Zoning of Insecurity Flood level Using Geographic Information Systems (GIS) in Walanae Hilir Sub-Watershed. Research Journal of Agriculture Engineering Departement of Hasanuddin University. http://repository.unhas.ac.id/handle/123456789/2004.

[8] GFA Consulting Group, Classification of Climate, 2011, Feasibility Study „Development of Jatropha Curcas Oil for Bio-Energy in Rural Areas ", Indonesia.

[9] Salman A.A., A.E. Ali and H.E. Mattar, 2008, Mapping Land-Use/Land-Cover Of Khartoum Using Fuzzy Classification, Emirates Journal for Engineering Research, 13 (2), 27-43 (2008).

[10] Zhan Qingming, Martien Molenaar, Ben Gorte, 2000, Urban Land Use Classes With Fuzzy Membership And Classification Based On Integration Of Remote Sensing And GIS, International Archives of Photogrammetry and Remote Sensing. Vol. XXXIII, Part B7, Amsterdam. 